\title{
A DOENÇA HOLANDESA NO BRASIL: SINTOMAS E EFEITOS
}

\author{
Diego Strack ${ }^{1}$ \\ André Filipe Zago de Azevedo
}

RESUMO: Desde 1977, quando a revista The Economist cunhou originalmente o termo doença holandesa, para caracterizar o fenômeno de desindustrialização de um país, provocada pela entrada de divisas internacionais provenientes da comercialização de uma riqueza natural abundante, o tema tem sido bastante controverso. Este artigo tem como objetivo a revisão teórica do fenômeno da doença holandesa e uma análise de sua ocorrência no Brasil. Esse tema desperta grande interesse no país, pois além da acentuada valorização cambial ocorrida nos últimos anos, a descoberta de grandes reservas de petróleo na camada do pré-sal no litoral do Brasil tem causado preocupações quanto aos seus efeitos na economia. Desta maneira, buscou-se conceituar o fenômeno e identificar os fatores que provocam a sua ocorrência. Foram analisados os principais sintomas e suas consequências, com ênfase no caso holandês, que deu origem ao nome do fenômeno. Atualmente, há duas visões antagônicas sobre a existência da doença holandesa no país: os que defendem a ocorrência do fenômeno, baseando-se em alguns sintomas da doença e os que refutam esta hipótese, a partir da análise da evolução da participação da indústria no PIB. Com base nesta discussão, e alicerçado em dados a partir de 2005, buscou-se verificar a presença da doença no país. Os resultados mostram que o fenômeno ainda não estaria presente na economia brasileira, pois não houve alteração significativa na participação do setor industrial no PIB brasileiro, apesar do acentuado processo de reprimarização da pauta exportadora do país.

Palavras-Chave: Doença holandesa. Reprimarização das exportações. Desindustrialização.

ABSTRACT: Since 1977, when The Economist first coined the expression dutch disease, to characterize the process of deindustrialization, caused by the entry of international reserves by the exports of an abundant natural resource, it has been very controversial. This paper revises the literature related to the dutch disease and examines whether it would be occurring in Brazil. This subject has provoked much interest in Brazil due to the overvaluation of its currency and the recent discovery of huge off-shore oil reserves, named as pré-sal. This paper presents its definition, its main symptoms and consequences, with emphasis in the dutch episode, which give name to this phenomenon. Nowadays, there are two diverging views about its existence in Brazil: those who support it, based on the some symptoms of the disease and its opponents, based on the evolution of the share of the industry on GDP. Having this discussion as a background, and based on data from 2005 , it sought to identify its presence on Brazil. The results, based on the shares of industry on GDP and exports, show that the dutch disease would not be present in Brazilian economy, as there was no significant changes of the participation of the industrial sector on GDP, despite the marked process of reprimarization of Brazilian exports.

Key-Words: Dutch disease. Export reprimarization. Desindustrialization.

\footnotetext{
${ }^{1}$ Possui graduação em Ciências Econômicas pela Universidade do Vale do Rio dos Sinos (UNISINOS). Email: diegostrack@gmail.com.

${ }^{2}$ Professor titular da Universidade do Vale do Rio dos Sinos (UNISINOS) e consultor econômico da Federação das Associações Comerciais do Rio Grande do Sul (FEDERASUL). E-mail: azevedo@unisinos.br.
}

Recebido em: 11/09/2012

Aceito em: 22/10/2012 


\section{INTRODUÇÃO}

No final dos anos 1950, a Holanda descobriu vastas reservas de gás natural no Mar do Norte e, após alguns anos, iniciou-se a exportação deste recurso natural. O que viria ser uma positiva fonte de renda acabou gerando um inconveniente processo de desindustrialização, trazendo prejuízos econômicos ao país. Para descrever este problema, em 1977, a revista The Economist cunhou o termo "dutch disease", ou doença holandesa. Segundo Bresser Pereira (2008), a doença holandesa é o fenômeno da valorização da taxa de câmbio, provocada pela entrada de divisas internacionais provenientes da comercialização da riqueza natural abundante (gás no caso Holandês). A desindustrialização ocorre devido a esta valorização do câmbio reduzir a competitividade do setor industrial exportador no mercado internacional. Como resultado, a participação da indústria no PIB do país diminui, bem como a participação do emprego industrial no emprego total.

Para tentar identificar as causas e consequiências deste problema, diversos autores, como Corden e Neary (1982), Bresser Pereira (2008), Gala (2006), Gomes Batista (2009), Nassif (2008), Onyeukwu (2007), Oomes e Kalcheva (2007), Ruehle e Kulkarni (2008), Bresser Pereira e Marconi (2010), Rocha e Marconi (2010), Lacerda e Nogueira (2008) e Nakahoto e Jank (2006) desenvolveram trabalhos em que foram discutidas as variáveis macroeconômicas que estariam envolvidas no desenvolvimento da doença holandesa, tratados em geral como "sintomas da doença".

Desde então, vários países passaram por processos semelhantes ao ocorrido com a Holanda. Experiências históricas em países como Chile, Nigéria e Azerbaijão foram examinados, respectivamente, por Ruehle e Kulkarni (2008), Onyeukwu (2007) e a revista The Economist (1997). Esses autores identificaram os sintomas e as respectivas commodities que poderiam estar provocando a doença holandesa nesses países.

Recentemente, houve uma descoberta de grandes reservas de petróleo na camada do pré-sal localizada no litoral do Brasil. Esta notícia tem sido levada apenas pelo lado positivo pelo governo, imprensa e população, mas não está sendo suficientemente considerada a possibilidade da ocorrência da doença holandesa no país. O fenômeno da doença holandesa pode exercer um efeito muito negativo sobre a economia de um país, conforme descrito acima. 
No caso brasileiro, mesmo antes da exploração do pré-sal, autores como Bresser Pereira (2008), Bresser Pereira e Marconi (2010), Rocha e Marconi (2010), Lacerda e Nogueira (2008) e Souza (2009), afirmam que o país já estaria vivendo um processo de desindustrialização, provocado pela doença holandesa. Entretanto, há uma segunda corrente de autores, como Nassif (2008), Nakahoto e Jank (2006) e Gomes Batista (2009), que refutam a ocorrência de tal fenômeno no país, mostrando que a participação da indústria no PIB total e do emprego industrial no emprego total não se alterou significativamente nos últimos 20 anos.

O presente trabalho tem como objetivo examinar quais são os principais sintomas da doença holandesa e avaliar a sua incidência sobre a economia brasileira, no período recente. Nesse sentido, este trabalho está dividido em cinco seções, além desta introdução. A seção 2 apresenta o histórico e o conceito de doença holandesa, enquanto a terceira examina seus sintomas. A seção 4 examina os argumentos contrários e favoráveis à existência da doença holandesa no Brasil e, a partir de dados recentes sobre a produção e exportações, busca identificar a sua incidência no país, a partir de 2005. A última seção apresenta as conclusões.

\section{DOENÇA HOLANDESA: HISTÓRICO E CONCEITO}

\subsection{O Caso Holandês}

Em 1977, a revista semanal inglesa "The Economist" utilizou pela primeira vez o termo "Dutch disease" para descrever um fenômeno que ocorria na Holanda nas décadas de 1960 e 1970. Com tradução literal de doença holandesa, esta remete a decadência da indústria holandesa após a descoberta de grandes reservas de gás natural no Mar do Norte. A excessiva entrada de divisas, ocasionada pela comercialização internacional do gás natural, provocou uma valorização do florim (moeda nacional holandesa na época). O setor industrial teve sua competitividade afetada, dado que, com o florim sobrevalorizado, seus preços internacionais não eram competitivos, que além de favorecer as importações, ocasionou um movimento de desindustrialização no país. 
De acordo com Gomes Batista (2009), a Holanda experimentava um período de prosperidade, com crescimento econômico sustentado que se manteve até quatro anos após a descoberta de reservas de gás natural, na Bacia do Mar do Norte, na região de Groningen, em 1959. O campo de Groningen abrigava estimados 2.700 milhões de metros cúbicos de gás natural, tanto onshore (em terra), quanto offshore (no mar).

Era esperado que o crescimento econômico se mantivesse no mesmo nível ou até mesmo aumentasse, mas durante a explosão das exportações dos recursos naturais encontrados, a economia surpreendentemente diminuiu seu ritmo de crescimento. Entre 1961 e 1969, a média anual de crescimento do PIB foi de 5,4\% e na década de 1970, o crescimento anual médio declinou para 3,3\%, quando se esperava um crescimento maior, pois o gás era substituto do petróleo, que sofreu duas crises em 1973 e 1979. Durante a década de 1980, a economia se encontrou em situação ainda mais delicada, com crescimento anual médio do PIB de apenas 2,2\%, experimentando nos anos de $1981 \mathrm{e}$ 1982, retração do PIB de $0,51 \%$ e $1,28 \%$, respectivamente.

As exportações de combustíveis, após apresentar uma queda acentuada no início dos anos 1960, passaram a crescer de forma significativa, a partir do final dos anos 1960. A participação das exportações de combustíveis que girava em torno de $10 \%$ do total exportado pela Holanda nos anos 1960, chegou a quase dobrar nos anos 1970, atingindo a $18,2 \%$, em 1977. Isto indica a commoditização da pauta de exportações, que é um dos principais sintomas da doença holandesa.

A média de valor do câmbio holandês em relação ao dólar se comportou de forma inversamente proporcional ao crescimento anual do PIB, à medida que as exportações de gás aumentaram, a taxa média de crescimento diminuiu, onde o gás foi a principal fonte de receita das exportações, sendo responsável pela entrada de divisas e provocando uma valorização do Florim. Durante os anos 1960, a taxa de câmbio se manteve estável e desvalorizada, devido ao efeito do acordo de Bretton Woods, mas assim que este foi abandonado, ocorreu uma valorização da taxa de câmbio, também ocasionada pela elevação dos preços internacionais das commodities exportadas pela Holanda.

Assim, se percebe que houve uma relação direta entre o aumento das exportações de combustíveis e a valorização da moeda holandesa, ao longo dos anos 1970. Agora resta examinar o que ocorreu com a indústria do país neste período. O gráfico 1 mostra que 
houve uma perda significativa da participação da indústria no PIB holandês durante os anos 1970, declinando de 38\%, em 1970, para 33\%, em 1979. Portanto, o quadro está completo, ou seja, a forte elevação das exportações de um produto básico (combustíveis) teria levado a uma apreciação cambial que, por sua vez, resultou na queda da participação da produção industrial no PIB do país. Gomes Batista (2009) conclui que a robustez da economia holandesa foi enfraquecida, em face da redução do setor manufatureiro na participação das exportações, ocasionada pelo aumento da exportação de recursos naturais e valorização do câmbio, provocando um processo de desindustrialização. ${ }^{3}$

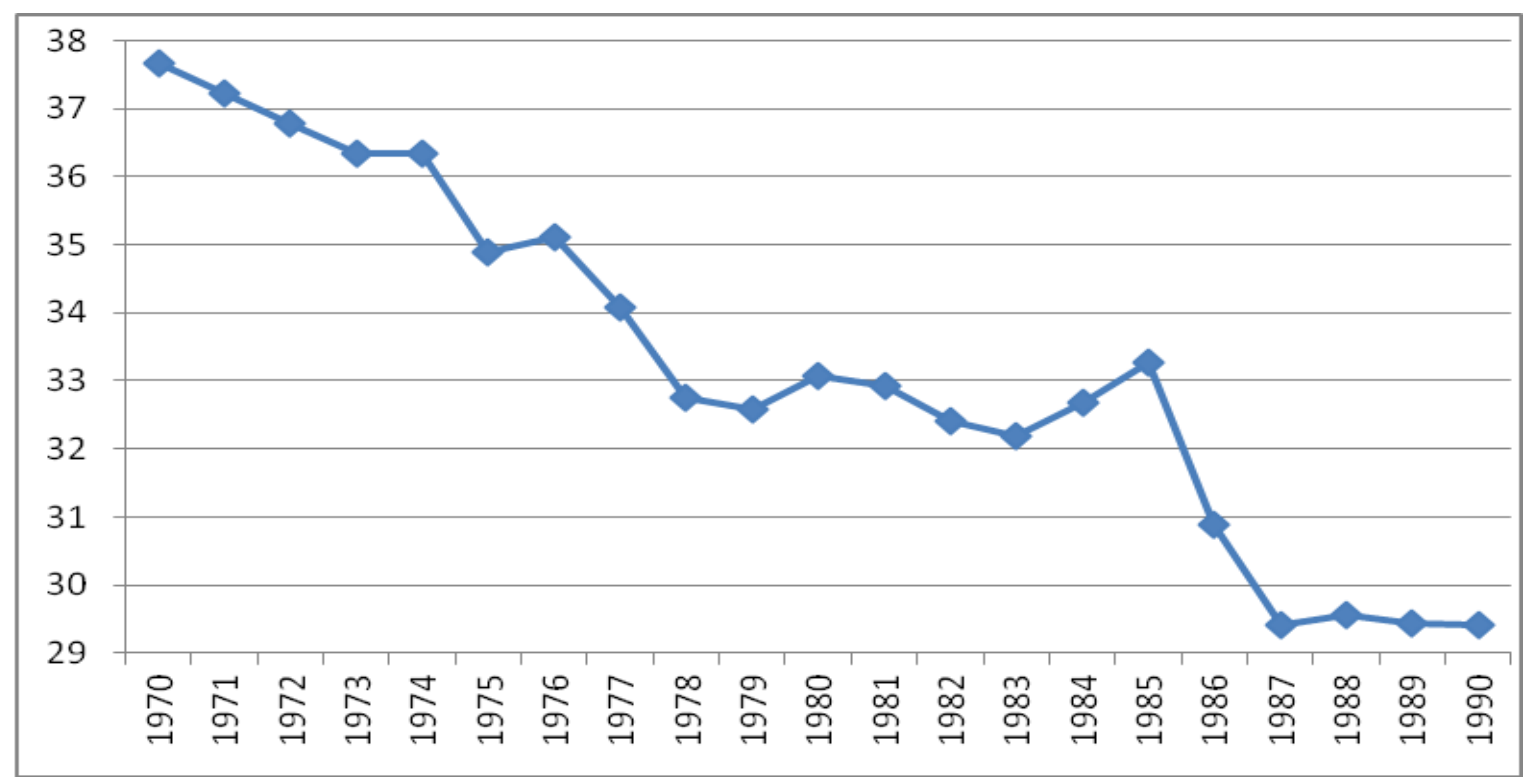

Gráfico 1 - Valor adicionado pela indústria (\%) em relação ao PIB holandês (1970 a 1990)

Fonte: Banco Mundial.

\subsection{O conceito de Doença Holandesa}

De acordo com Souza (2009), o teorema de Rybczynski (1955) aponta que um aumento na dotação de um fator de produção amplia a produção do setor que o utiliza de forma intensiva e, consequentemente, diminui a produção do outro setor, dado que os preços de fatores são considerados constantes. Isto demonstra que a doença holandesa é

\footnotetext{
${ }^{3}$ A desindustrialização parece não estar mais ocorrendo a partir da segunda metade da década de 1980, pois cai vertiginosamente a parcela de gás na pauta de exportações, simultaneamente com a valorização do Florim, que não parece ter impactado na recuperação do crescimento médio anual do PIB, que foi de $3,8 \%$, entre 1985 e 1989.
} 
produto de uma aplicação direta deste teorema. Um exemplo é, no caso de novas descobertas de petróleo, a produção do setor primário (extrativo) da economia aumentar em detrimento da produção do setor secundário (industrial).

A doença holandesa se manifesta com o aparecimento de alguns sintomas relacionados entre si, como a commoditização da pauta de exportações, apreciação da taxa de câmbio, decréscimo da participação da indústria de bens comercializáveis no produto total do país e aumento dos salários nos setores de serviços e no setor do "boom”, como destaca Bresser Pereira (2008). O autor afirma que há uma maneira de ampliar o conceito de doença holandesa, de maneira que seja incluída também a mão de obra barata como causa, e se isto se mostrar verdadeiro, a doença se torna ainda mais geral. Países como China e Índia teriam a doença e se desenvolveriam apenas com a sua neutralização, através da administração da taxa de câmbio, como vêm fazendo estes países e também todos os países asiáticos dinâmicos. Neste caso, é necessário considerar o problema do crescimento econômico dado pela transferência de mão de obra, que sai dos setores de menor valor para os de maior valor agregado. Em princípio, os bens produzidos com a utilização de mão de obra barata exigem pouca qualificação e, por isto, são produtos com baixa intensidade tecnológica.

De acordo com o autor, as rendas ricardianas são rendas provenientes do comércio de produtos no mercado internacional, produtos os quais os países se especializaram em produzir devido à sua dotação de recursos, que representam uma vantagem comparativa (custo relativo menor por unidade produzida) em relação a outros países que não possuem tais dotações. Para Bresser Pereira (2008), as indústrias que utilizam intensivamente mão de obra barata têm um custo marginal mais baixo em relação ao mesmo custo das indústrias intensivas em tecnologia. Devido a isto, a taxa de câmbio tende a convergir para o nível que torna a exportação de bens que utilizam mão de obra barata mais rentável. Na medida em que nas indústrias mais sofisticadas os salários são desproporcionalmente maiores - os produtos que utilizam tal tecnologia (e mão de obra mais cara devido à sua maior qualificação) ficariam economicamente inviabilizados.

O autor afirma que, caso a diferença salarial, por exemplo, de um trabalhador pouco qualificado para um engenheiro for cerca de 3 a 4 vezes, como é nos países ricos, este país teria condições de produzir qualquer tipo de bem com mão de obra barata, sem o 
surgimento de outras dificuldades a não ser as técnicas e administrativas. Porém, se a diferença no leque de salários for maior no país que possui mão de obra barata, o problema da doença holandesa ampliada ocorreria. Considerando que é comum a diferença de leque salarial de 10 a 12 vezes em países em desenvolvimento, e de 3 a 4 vezes em países ricos, então a doença existirá, pois as indústrias intensivas em tecnologia necessitarão de uma taxa de câmbio corrente maior do que a de equilíbrio determinada pelo mercado.

\section{SINTOMAS DA DOENÇA HOLANDESA}

\subsection{Aumento das Exportações de Produtos Primários}

De acordo com Corden e Neary (1982), a doença holandesa se manifesta através de um primeiro sintoma, que é o boom das exportações de recursos naturais, seja esta através da descoberta de novas reservas ou da ampliação da extração dos recursos já existentes. Este boom é necessário para desencadear os outros sintomas, dado que o aumento das exportações de commodities provoca alterações na estrutura e no desempenho econômico do país.

Gomes Batista (2009) afirma que o nível de dependência econômica das commodities que o país possui está relacionado com a dimensão do impacto da doença na economia de modo geral. Essa dependência pode ser identificada através da quantidade de commodities comercializadas e sua participação nas exportações. Os preços internacionais das commodities exportadas pelo país também são um fator importante, pois além da quantidade exportada, estes também determinam a obtenção de uma maior ou menor renda proveniente do comércio internacional.

\subsection{Apreciação Real da Taxa de Câmbio}

Corden e Neary (1982) afirmam que o aumento repentino das exportações de commodities tem relação com a apreciação da taxa de câmbio. A ampliação das exportações gera uma entrada de divisas maior que o fluxo anterior ao boom, isto provoca uma apreciação da moeda nacional frente à moeda internacional, pois em um regime de câmbio flexível, o excesso de oferta de moeda estrangeira faz o câmbio apreciar-se. 
De acordo com Bresser Pereira (2008), a taxa de câmbio de equilíbrio anterior ao boom é a taxa que mantinha o nível de competitividade da indústria manufatureira exportadora. No entanto, dado o aumento causado pela elevação das exportações de commodities, a taxa de equilíbrio se valoriza, prejudicando o setor manufatureiro, que perde competitividade devido ao câmbio sobrevalorizado. O autor afirma ainda que o setor primário não é tão afetado com uma taxa de câmbio maior, pois utiliza recursos naturais abundantes e de baixo custo, enquanto o setor de bens comercializáveis necessita de uma taxa mais baixa, pois é tecnologicamente mais avançado e os insumos utilizados têm preço maior, em relação ao setor primário. Mesmo com uma tecnologia em "estado de arte" e alta produtividade, o setor de bens comercializáveis sofre com o câmbio sobrevalorizado.

No trabalho de Oomes e Kalcheva (2007), a relação entre os preços das commodities e a taxa de câmbio foi examinada. Foram estimadas as relações de longo prazo entre a taxa real de câmbio e seus determinantes, através do método do Equilíbrio Comportamental da Taxa de Câmbio russa, e os erros foram interpretados como desalinhamentos na taxa de câmbio. Os autores afirmam que, assim como a hipótese da doença holandesa supõe, suas estimativas sugerem que a elevada taxa de câmbio real é resultado dos altos preços das commodities exportadas. Um aumento de $1 \%$ no preço do petróleo (commodity usada no estudo de Oomes e Kalcheva, 2007) acarreta uma elevação de $0,5 \%$ da taxa de câmbio real russa.

Outra conclusão obtida pelos autores, é que a acumulação de reservas internacionais está negativamente relacionada com a apreciação real da taxa de câmbio, em razão de que $1 \%$ de acréscimo nas reservas internacionais ocasiona uma redução da taxa real de câmbio de $0,18 \%$. Contudo as intervenções na taxa de câmbio real feitas com as reservas internacionais devem ser teoricamente nulas no longo prazo, pois o uso de reservas não esterilizadas provocam inflação, que compensará o efeito negativo de curto prazo na taxa real.

\subsection{Redução da Participação da Indústria no PIB e do Emprego Industrial Total}

Bresser Pereira (2008) afirma que a apreciação real da taxa de câmbio, provocada pelo aumento das exportações de commodities, é o fator que causa a perda de competitividade da indústria manufatureira. Isto de dá, porque a taxa de câmbio de equilíbrio, que aufere competitividade ao setor de manufaturados, é maior que a taxa de 
câmbio que proporciona competitividade ao setor primário. Como o boom provoca uma valorização da taxa de câmbio, o setor manufatureiro é prejudicado, pois perde competitividade, em benefício do setor primário. Para o autor, esse desalinhamento entre as duas taxas é prejudicial ao país como um todo, principalmente para o setor industrial, pois com o câmbio elevado, este perde a competitividade de seus produtos em nível internacional. A valorização do câmbio torna os produtos importados mais baratos, aumentando o consumo destes em detrimento dos produtos nacionais, prejudicando a produção nacional a ponto de desestimular o investimento e a inovação. A redução da participação industrial é uma consequiência destes eventos, e sua ocorrência, no longo prazo, acarreta a desindustrialização do país que sofre a doença.

Corden e Neary (1982) indicam em seu modelo, que existe uma movimentação de trabalho na economia durante o boom das exportações de produtos primários. Dado que o setor primário utiliza uma série de recursos, que podem ser realocados de outros setores para este, o trabalho é um destes fatores realocados. Quando ocorre o boom, a demanda por profissionais aumenta por parte do setor primário, e este dispõe de recursos para atrair profissionais de outras áreas, isto é, pode remunerar melhor a mão de obra. Ocorre então um movimento de trabalhadores para o setor, que saem do setor secundário, que devido à perda de competitividade, oferecem remunerações inferiores. ${ }^{4}$

\section{DOENÇA HOLANDESA NO BRASIL}

Atualmente, há um grande debate no Brasil a respeito da existência ou não da doença holandesa no país. De um lado, alguns economistas (por exemplo, BRESSER PEREIRA, 2008; BRESSER PEREIRA; MARCONI, 2010; ROCHA; MARCONI, 2010; LACERDA; NOGUEIRA, 2008) defendem a tese de que o país já seria alvo da doença. O desenvolvimento dos biocombustíveis, o aumento da demanda mundial do etanol e a possibilidade de extração de petróleo na camada pré-sal vêm trazendo crescentes preocupações com o fenômeno da doença holandesa no país. A expectativa do aumento das exportações de commodities e a constante valorização do real perante o dólar já estaria trazendo problemas de competitividade em nível internacional para a indústria brasileira.

\footnotetext{
${ }^{4}$ Os autores afirmam que o setor de serviços, por sua vez também perde trabalhadores para o setor primário, porém este possui condições de acompanhar o aumento dos salários, perdendo menos mão de obra em relação ao setor secundário. O setor secundário sofre ausência de dois fatores, a competitividade, ocasionada pela taxa de câmbio apreciada, e do trabalho, provocado pela pressão de alta dos salários, e com isso o setor tende a diminuir sua participação no PIB, ocorrendo o fenômeno da desindustrialização.
} 
De acordo com Souza (2009), medidas que evitaram a valorização do câmbio deixaram o Brasil a salvo dos efeitos nocivos da doença holandesa até os anos 1990, mas o país teria sofrido grande desindustrialização após a liberalização comercial e financeira, ocorrida a partir dos anos 1990. Assim, o país teria retornado a sua posição ricardiana de exportador de recursos naturais, devido a não adoção de políticas industriais e comerciais ativas e o uso da valorização cambial como combate à inflação. Para o autor, existe a dúvida de quais fatores levaram o país e desenvolver a "doença": a descoberta de novos recursos ou o rumo que a política econômica tomou após $1990 .^{5}$

No entanto, afirmar que a exportação de commodities é a causa da desindustrialização é fazer uma demasiada simplificação, pois outros fatores, como a falta de política tecnológica e científica, má conservação da infraestrutura e altos impostos e juros, também são causadores de desindustrialização. Nesse sentido, outros autores (por exemplo, NAKAHOTO; JANK, 2006; NASSIF, 2008; GOMES BATISTA, 2009; SQUEFF, 2012) refutam a hipótese de existência da doença holandesa no país.

Nassif (2008) coloca a doença holandesa no Brasil sob outra perspectiva, o qual afirma que o processo de desindustrialização poderia ter ocorrido pela via "natural", onde a descoberta de recursos naturais é responsável pela desindustrialização em economias em estágios mais avançados, ou pelo processo da "nova doença holandesa", caracterizado pelo abandono do antigo regime de substituição de importações e o retorno do padrão de especialização produtiva em recursos naturais, aliada às políticas de liberalização financeira e comercial. A conclusão do autor é de que o país já possuía uma forte perda da participação do setor industrial no PIB, a partir da metade da década de 1980, provocada por uma estagnação econômica e uma perda da produtividade do trabalho, isto é, antes da liberalização econômica ocorrida apenas na década de $1990 .^{6}$

\footnotetext{
${ }^{5} \mathrm{O}$ autor aponta que a competitividade da indústria brasileira pode ser reduzida ainda mais, pois o Brasil está negociando, na rodada de Doha da OMC, a diminuição de subsídios que a Europa e os Estados Unidos dão à agricultura, e estes em contraponto exigem a redução de taxas aduaneiras em setores importantes da indústria.

${ }^{6} \mathrm{O}$ estudo alerta para riscos de longo prazo, relacionados à tendência a sobrevalorização real da moeda nacional em relação ao dólar, ocorrida desde a década de 1980 até 2006, com exceção do período de 1999 a 2003. Estes riscos, segundo o autor, estão relacionados à perda de competitividade do setor industrial, ao início de um processo de desindustrialização, o qual ainda seria uma conjectura, mas no longo prazo poderia se transformar em um fenômeno real.
} 


\subsection{Os argumentos pró-doença holandesa no Brasil}

Alguns autores indicam a existência da doença holandesa no Brasil, com destaque para Bresser Pereira (2008), Rocha e Marconi (2010), Lacerda e Nogueira (2008) e Souza (2009). Para Bresser Pereira (2008), os países que sofrem da doença holandesa se dividem em dois grupos. No primeiro, os países exportaram um recurso natural por um período e nunca se industrializaram, ou alcançaram a industrialização por certo período, mas depois sofreram com uma desindustrialização prematura. Neste caso, não houve neutralização da doença holandesa em nenhum momento, e esta se tornou, relativamente permanente, refletindo um sintoma claro da falta de outros bens comercializáveis. Se o país obtém rendas ricardianas provenientes da exportação de um recurso natural, isto lhe permite uma acumulação de capital para a formação de uma classe empresarial significativa, mas se esta não se forma, é um sintoma de grave doença holandesa.

No segundo grupo, os países que exportaram recursos naturais e, ao mesmo tempo, lograram industrialização, neutralizando a doença holandesa, alcançaram esta situação com o uso de tarifas de importação e subsídios à exportação, mas devido a pressões internacionais, abandonaram estas medidas sob acusação de protecionismo e também em nome da liberalização comercial. Assim, a indústria de transformação começa a sofrer os efeitos da valorização cambial e se inicia a desindustrialização prematura. Se a intensidade da doença holandesa for de grande proporção, os sintomas da desindustrialização se tornam mais evidentes, apontando a redução da participação da indústria de transformação no produto nacional e nas exportações líquidas (em termos de valor agregado).

Ainda segundo o autor, isto teria ocorrido nos países latino-americanos, a partir da década de 1990, quando houve um abandono das medidas de neutralização da doença holandesa. Na década seguinte, a situação se tornou ainda mais grave para países de maior industrialização como o México e o Brasil, pois a eliminação das medidas neutralizadoras ocasionou a apreciação real da taxa de câmbio, gerada pela alta dos preços internacionais das commodities por estes exportadas. ${ }^{7}$

\footnotetext{
${ }^{7}$ Frente à identificação de que a desindustrialização está em marcha e sua razão é a doença holandesa, outro sintoma é a recusa dos economistas convencionais de aceitar tal diagnóstico, juntamente com os que têm interesses de curto prazo na manutenção da situação. Outros economistas mais radicais afirmarão que é possível obter o crescimento econômico apesar de a desindustrialização estar ocorrendo, mas a doença
} 
De acordo com Bresser Pereira (2008), no momento em que um país começa a se industrializar, seu crescimento econômico depende do sucesso da neutralização da doença holandesa, e foi isto que ocorreu no século XX com todos os países latino-americanos e asiáticos que se industrializaram. ${ }^{8}$ Segundo o autor, no período que compreende os anos de 1930 e 1980, em especial, México e Brasil obtiveram extraordinário crescimento industrializando-se, devido à adoção de medidas que neutralizaram a doença holandesa. Em geral, estas medidas compreenderam a adoção de múltiplas taxas de câmbio ou de tarifas de importação em conjunto com subsídios à exportação, que na verdade resolveram o problema ao alcançarem a depreciação da moeda para produtores de industriais, apesar dos políticos e economistas não terem conhecimento sobre doença holandesa na época.

De acordo com o autor, também é necessário levar em consideração que os recursos naturais são finitos, e ainda, caso haja especialização em commodities não esgotáveis, como as que utilizam recursos agrícolas, é preciso confirmar se a produção de tais commodities terá condições de empregar toda a população. Mesmo com abundância em terras agricultáveis não utilizadas, é provável que esta condição não seja satisfeita. Um exemplo é o caso brasileiro, onde mesmo que a produção de cana-de-açúcar, soja, laranja e madeira tripliquem, haverá apenas o emprego de uma pequena parcela de mão de obra. No Brasil, não existe previsão da quase total destruição de sua indústria de transformação, pois a doença holandesa não é tão grave. O país deixou de neutralizá-la quando realizou sua abertura comercial e financeira, no período de 1990 a 1992, eliminando o imposto implícito até então existente, e depois houve um agravamento da doença devido ao aumento da demanda chinesa por commodities, provocando elevação dos preços destas.

Rocha e Marconi (2010), em concordância com Bresser Pereira (2008), afirmam que a intensidade da participação das commodities na pauta de exportações nos países latino-americanos é um fator-chave que colabora para a contínua apreciação do câmbio, e isto pode ser associado com a ocorrência da doença holandesa, dado que esta apreciação é um dos seus principais sintomas. Os autores explicam que a não ocorrência de doença holandesa em alguns países do sudeste asiático, onde a exportação de commodities não

holandesa se mostra presente e atuante, pois a própria lógica da valorização cambial sem queda do saldo da balança comercial, indicam sua ocorrência.

${ }^{8}$ Um exemplo é o dos países latino-americanos que possuem grandes recursos minerais e agrícolas, que aproveitaram para implantar um setor produtor e exportador de bens primários, mas a partir dos anos de 1930, obtiveram êxito no desafio de se industrializar, dado que se haviam esgotadas suas virtualidades na via da produção e exportação dos bens primários. 
afetou o câmbio, estaria relacionada ao regime de câmbio adotado, que seria mantido em um nível que proporciona maior competitividade às exportações. Os países da América Latina, ao contrário do caso asiático, apresentaram taxas de câmbio valorizadas em relação ao seu nível de equilíbrio em longo prazo, não neutralizando a doença.

Bresser Pereira e Marconi (2010) afirmam que, entre 1992 e 2007, o fenômeno da doença holandesa estaria se manifestando no Brasil através de outros sintomas que vão além da apreciação da taxa de câmbio. A balança comercial das commodities evoluiu positivamente após 1992, em contraste com a dos produtos manufaturados, que retraiu neste mesmo período. A evolução da balança comercial das commodities, sem associação com a taxa de câmbio, indica a influência de outros fatores no comércio destes bens, especialmente o preço das exportações, que teria crescido menos no caso dos bens manufaturados em relação ao das commodities. Porém alguns outros sintomas da doença holandesa estariam visíveis, como redução do saldo da balança dos manufaturados e aumento no saldo das commodities, diminuição da participação de manufaturados nas exportações totais e também a mudança na alocação de fatores produtivos a favor da produção de commodities. $\mathrm{O}$ autor revela que estes são apenas indícios de desindustrialização, mas se este cenário se mantiver, futuramente esta ocorrerá.

Em sintonia com a visão de Bresser Pereira (2008) e Bresser Pereira e Marconi (2010), Lacerda e Nogueira (2008) afirmam que estas condições anteriormente citadas têm provocado ações de defesa das empresas manufatureiras, que prejudicam os resultados macroeconômicos, especialmente quanto à desindustrialização, explicado da seguinte maneira: a apreciação do câmbio faz com que as empresas dêem preferência na importação de bens que são insumos para a fabricação de seus produtos, com intenção de reduzir custos e maximizar seu lucro, mesmo que isto signifique o comprometimento da estrutura produtiva brasileira. Os autores afirmam ainda que seria necessário aperfeiçoar as políticas monetária, cambial e fiscal, a fim de proporcionar condições para evitar que essa situação se perpetue.

Em linhas gerais, Bresser Pereira (2008), Rocha e Marconi (2010), Bresser Pereira e Marconi (2010), Lacerda e Nogueira (2008) e Souza (2009) defendem a ocorrência da doença holandesa no Brasil, pois o país teve uma acentuada valorização cambial, a partir dos anos de 1990, que chegou a 37\% somente entre 2005 e 2008 (LACERDA; 
NOGUEIRA, 2008), um aumento da participação das commodities na pauta de exportações, de 23\% em 2000 para 33\% em 2007 (LACERDA; NOGUEIRA, 2008), e redução na participação da indústria no PIB total, de 43,5\% em 1992 para 41,1\% em 2007 (Bresser Pereira e Marconi (2010)), todos estes sendo sintomas da doença holandesa.

\subsection{Os argumentos contrários à existência da doença holandesa no Brasil}

Em seu estudo, Nassif (2008) analisa o caso brasileiro e afirma que não há ocorrência de doença holandesa no Brasil. Segundo ele, a combinação de políticas macroeconômicas e medidas liberalizantes, que apreciam o câmbio, teriam feito com que o Brasil contraísse a "nova doença holandesa", pois estas medidas modificaram o padrão de especialização internacional, direcionando a pauta de exportações para a venda de produtos primários e de bens industrializados intensivos em recursos naturais.

Os vários tipos de segmentos industriais são classificados por tipo de tecnologia, proposta pela OECD (1987). O autor utiliza a tese de Pavitt (1984), que associa cada tipo de tecnologia ao fator preponderante que aloca a posição competitiva dos setores e empresas no curto e longo prazo. O principal fator competitivo é o acesso aos vastos recursos naturais que existem no país, no caso das indústrias que utilizam tecnologia intensiva nestes recursos e nas intensivas em trabalho, o fator competitivo é a oferta de mão de obra de média e baixa qualificação, que é mais barata em relação a outros países.

Nassif (2008) aponta que, nos setores intensivos em escala, o principal fator de competitividade é a possibilidade de obter ganhos justamente por produzir em escala, já nos setores que utilizam tecnologia diferenciada, os diferentes padrões de demanda são o objetivo da fabricação de bens para atender tais necessidades, e ainda para as indústrias science-head, a alta velocidade de aplicação da pesquisa científica às tecnologias industriais é o principal fator que proporciona sua competitividade. De maneira geral, o autor ainda afirma que a maior capacidade para gerar empregos diretos é oferecida pelos setores intensivos em tecnologia baseada em recursos naturais e intensivos em trabalho. Os setores de tecnologia intensiva em escala, diferenciada e baseadas em ciência, por sua vez, possuem maior capacidade para promover efeitos de encadeamento para frente e para trás, devido ao fato de terem maior intensidade na relação capital/trabalho, onde os efeitos multiplicadores de renda e emprego são superiores às demais, também contribuindo para a difusão de inovações para o restante da economia. 
Nassif (2008) considera que, para que a hipótese da "nova doença holandesa", baseada na desindustrialização, seja válida para o caso brasileiro, uma parcela considerável dos segmentos constituintes de indústrias de tecnologia intensiva em escala, diferenciada e baseada em ciência, necessitará mostrar evidências de simultânea redução na participação do valor adicionado e na parcela que ocupa nas exportações totais da indústria. Para efeitos gerais, o autor coloca que é possível simplificar o comportamento das exportações industriais em dois sub-períodos: primeiro de 1989 a 1999, onde a apreciação cambial afetou as taxas de crescimento das exportações de produtos industrializados brasileiros em relação às exportações do resto do mundo, ocasionando uma estagnação; e segundo, do "boom” que ocorreu após 1999, onde as significativas taxas de crescimento médias anuais das exportações brasileiras de produtos industrializados foram resultados da tendência de depreciação da moeda (1999 a 2003), elevadas taxas de crescimento da economia mundial (após 2003) e da alta dos preços das commodities exportadas pelo país (em especial 2004 e 2005)..$^{9}$

No entanto, Nassif (2008) acredita que é cedo para afirmar que as mudanças citadas, ocorridas no Brasil, são sintomas de desindustrialização, pois no período entre 1989 e 2005, os setores com tecnologias diferenciadas e baseadas em ciência aumentaram apenas marginalmente a participação nas exportações, de $10,1 \%$ para $11,1 \%$ e, respectivamente, de 3,8\% para 4,9\%. Neste mesmo período, o grupo de setores com tecnologias baseadas em recursos naturais ampliou sua participação nas exportações de petróleo e gás, de um valor ínfimo até 1999 para quase 4\% do total de produtos industrializados. Devido ao fato de o Brasil não ter passado por um processo generalizado de realocação dos recursos produtivos e alteração no padrão de especialização dos setores supracitados, segundo o autor, não se pode concluir que houve desindustrialização no país.

Segundo Nakahoto e Jank (2006), muitos argumentos têm se baseado apenas em impressões e não em dados analíticos. A conclusão por eles apresentada aponta diversos fatores que refutam a idéia da ocorrência da doença holandesa no Brasil. Os autores afirmam que o país obteve um crescimento médio de commodities e produtos diferenciados

\footnotetext{
${ }^{9}$ As mudanças observadas nas participações de cada setor em relação ao total das exportações confirmam uma leve alteração do padrão de especialização internacional. O conjunto dos setores com tecnologia intensiva, baseado em recursos naturais e intensivos em trabalho representava, em relação ao total exportado, $50 \%$ em 1989, evoluindo para 53,3\% em 2005. Entretanto, os três outros grupos tiveram sua participação reduzida no mesmo período, de $49,9 \%$ para $46,7 \%$.
} 
(não commoditizados) de 6,8\% ao ano, desde 1996. As commodities cresceram mais $(8,5 \%$ a.a.) do que os produtos diferenciados (5,6\% a.a.), e dentre dos diferenciados, os setores de média e alta tecnologia mostraram uma dinâmica exportadora surpreendente. $\mathrm{O}$ valor das commodities no total da pauta brasileira cresceu pouco na última década (cerca de $30 \%$ a $40 \%$ da pauta). Notavelmente, o país aproveitou a oportunidade de expansão do comércio mundial, mesmo que abaixo do potencial e globalmente menor que outras economias emergentes.

Nakahoto e Jank (2006) entendem que o impacto sobre as exportações brasileiras causado pelos preços internacionais das commodities deve ser tratado com cuidado, pois o método de mensuração que dá um peso excessivo aos bens energéticos é enganoso e deve ser abandonado. O Fundo Monetário Internacional calcula o "Índice de Preços de Commodities Primárias", atribuindo $40 \%$ da ponderação ao petróleo, que representa somente $2,8 \%$ das exportações brasileiras. Por esta razão, o trabalho dos autores propõe a mensuração dos preços internacionais de acordo com um índice composto por produtos que formam a pauta de exportações brasileiras, no período de 1996 a 2005, em especial pela considerável participação de produtos dos setores agropecuário e agroindustrial.

O índice desenvolvido pelos autores aponta que a alta dos preços de commodities observada em 2005 não é diferente de outros ciclos no passado (1996, 1997 e final dos anos 1980), exceto o petróleo e o minério de ferro, os quais os preços internacionais subiram expressivamente. A conclusão dos autores é de descartar a equivocada sugestão de taxação das exportações das commodities, propostas por alguns especialistas, dada a inexistência do uma alta história e duradoura dos preços destes bens. Os autores concluem que a hipótese de que haveria desindustrialização em curso no Brasil é rebatida pelos superávits da balança comercial nos produtos não-commoditizados após 2002 e pela recuperação do emprego industrial, em $2004 .^{10}$

Gomes Batista (2009) afirma que o Brasil não sofre, com o minério de ferro, dos mesmos efeitos nocivos que a Holanda sofreu por exportar gás, e seu trabalho refuta essa hipótese com base na abertura comercial brasileira, sofisticação dos mercados futuros e transações interbancárias, além da diversificada pauta de exportação. Na concepção do

\footnotetext{
${ }^{10}$ Existe ainda a idéia simplista de que produzir commodities não seria uma "atividade industrial", mas no Brasil há uma rede de indústrias de insumos, máquinas e processamento de produtos e serviços que dão suporte a esta produção.
} 
autor, mesmo com a commoditização em andamento, não se pode relacionar o fenômeno entre estes países e seus respectivos produtos, dado que o montante exportado e os percentuais de participação nas exportações são muito diferentes. Desta maneira, nem mesmo um expressivo aumento das exportações de commodities seria capaz de aumentar sensivelmente o câmbio nacional ao patamar de causar a doença holandesa.

Squeff (2012), por sua vez, examina a hipótese de desindustrialização brasileira através da estrutura e dinâmica da indústria de transformação em relação ao restante da economia. O autor utiliza variáveis como produção, emprego e desempenho da balança comercial. Embora constate uma pequena redução da participação da indústria no PIB brasileiro, o mesmo não estaria ocorrendo com o emprego industrial, que desde 1995 estaria estável, em torno de $13 \%$ do total de empregos da economia. Além disso, o autor reconhece que a tendência de queda da indústria no valor agregado teria tido início há três décadas, ainda antes do processo de abertura comercial dos anos 1990.

Em suma, Nassif (2008), Nakahoto e Jank (2006), Gomes Batista (2009) e Squeff (2012) refutam a hipótese da ocorrência da doença holandesa no Brasil, pois segundo eles, o país não teve um movimento de desindustrialização e as hipóteses de ocorrência de doença holandesa são levantadas com base em impressões e não em dados analíticos. Os dados utilizados em seus estudos apontaram um leve crescimento dos setores intensivos em tecnologia e baseados em ciência, juntamente com o setor primário, e isto seria fruto de um proveito das oportunidades de expansão econômica mundial, uma mudança no padrão de especialização internacional e também conseqüências da abertura econômica, ocorrida no início da década de 1990.

\subsection{Doença Holandesa no Brasil: evidência recente}

De acordo com as linhas gerais dos autores já mencionados, se discute nesta seção a questão da existência da doença holandesa no Brasil, no período mais recente, através da análise de tabelas que mostram a evolução das exportações e do valor adicionado por segmento no PIB, dividida de acordo com seu uso intensivo, como recursos naturais, trabalho, escala, baseada em ciência e diferenciada. Conforme Nassif (2008) fez em sua análise, abrangendo o período de 1996 a 2004, se utiliza este período com adição de dados 
até 2007. A tabela 1 mostra os valores adicionados por cada setor no PIB total brasileiro, onde se podem ver as variações na participação ocorridas em cada setor, no período 19962007. ${ }^{11}$

Para que se possa afirmar que o Brasil esteja sofrendo de doença holandesa, é necessário que houvesse alterações simultâneas e significativas nos setores de indústria intensiva em tecnologia, intensiva em escala, diferenciada e baseada em ciência, com perdas na participação do PIB total. Conforme Nassif (2008) concluiu, no período de 1996 a 2004, não houve manifestação de sintomas da doença.

No período de 2005 a 2007, a participação do setor da indústria baseado em recursos naturais no valor adicionado total passou de $42,49 \%$ para $41,04 \%$, apresentando uma pequena queda, porém esta não pode ser considerada significativa. $\mathrm{O}$ setor industrial intensivo em trabalho, por sua vez, obteve aumento de participação de 9,81\% em 2005 para $10,17 \%$ em 2007. A indústria intensiva em escala também obteve aumento de sua participação de 34,44\% a 34,63\%, no mesmo período, e a indústria diferenciada também cresceu, neste período, de $10,03 \%$ para $10,56 \%$. O setor industrial baseado em ciência passou de 4,78\%, em 2005, para 4,59\%, em 2007, sinalizando uma pequena queda, mas também não significativa.

De maneira geral, houve crescimento nos setores industriais intensivos em trabalho, intensivo em escala e indústria diferenciada, e pequena queda nos setores intensivos em recursos naturais e baseados em tecnologia, indicando que não houve alterações significativas para considerar-se a hipótese da doença holandesa no país. Esta conclusão se baseia na teoria da doença holandesa, onde seria necessário aumento significativo de participação do setor intensivo em recursos naturais, ao lado de uma queda, também significativa, nos setores intensivos em trabalho, escala, ciência e diferenciada.

\footnotetext{
${ }^{11}$ Não foi possível atualizar os dados da produção industrial até 2010, porque houve uma alteração na classificação CNAE do IBGE a partir de 2008. Desta forma, a nova classificação não permite uma perfeita correspondência entre os setores com os anos anteriores, no qual Nassif (2008) se baseou, o que impediria uma comparação entre este trabalho e o trabalho do autor.
} 
Tabela 1 - Participação setorial no PIB total brasileiro de 1996 a 2007

\begin{tabular}{|c|c|c|c|c|c|c|c|c|c|c|c|c|}
\hline \multicolumn{13}{|c|}{ Valor adicionado setorial (\%) } \\
\hline SETORES INDUSTRIAIS COM TECNOLOGIA & 1996 & 1997 & 1998 & 1999 & 2000 & 2001 & 2002 & 2003 & 2004 & 2005 & 2006 & 2007 \\
\hline Baseada em recursos naturais & 32,70 & 32,09 & 33,36 & 36,79 & 38,32 & 39,15 & 40,05 & 42,47 & 40,10 & 42,49 & 43,25 & 41,04 \\
\hline 10 Extração de carvão mineral & 0,07 & 0,08 & 0,08 & 0,07 & 0,08 & 0,06 & 0,06 & 0,06 & 0,07 & 0,07 & 0,06 & 0,07 \\
\hline $\begin{array}{l}11 \text { Extração de petróleo e serviços } \\
\text { relacionados }\end{array}$ & 0,03 & 0,03 & 0,05 & 0,04 & 0,05 & 0,09 & 0,25 & 0,32 & 0,34 & 0,42 & 0,36 & 0,42 \\
\hline 13 Extração de minerais metálicos & 1,46 & 1,55 & 1,87 & 2,28 & 2,07 & 2,21 & 2,28 & 2,22 & 2,52 & 3,24 & 3,07 & 2,98 \\
\hline 14 Extração de minerais não-metálicos & 0,68 & 0,62 & 0,65 & 0,62 & 0,58 & 0,58 & 0,56 & 0,56 & 0,52 & 0,51 & 0,52 & 0,55 \\
\hline $\begin{array}{l}15 \text { Fabricação de produtos alimentícios e } \\
\text { bebidas }\end{array}$ & 17,22 & 17,53 & 17,69 & 16,45 & 14,05 & 16,09 & 16,26 & 16,20 & 15,22 & 15,81 & 15,98 & 15,35 \\
\hline 16 Fabricação de produtos do fumo & 1,10 & 1,03 & 0,95 & 1,04 & 0,80 & 0,87 & 0,85 & 0,78 & 0,73 & 0,67 & 0,72 & 0,72 \\
\hline 19.1 Curtimento e outras preparações de couro & 0,30 & 0,28 & 0,23 & 0,25 & 0,22 & 0,31 & 0,36 & 0,33 & 0,34 & 0,29 & 0,26 & 0,23 \\
\hline 20 Fabricação de produtos de madeira & 1,11 & 1,13 & 1,10 & 1,39 & 1,20 & 1,26 & 1,41 & 1,68 & 1,69 & 1,4 & 1,32 & 1,31 \\
\hline $\begin{array}{l}21.1 \text { Fabricação de celulose e outras pastas } \\
\text { para a fabricação de papel }\end{array}$ & 0,67 & 0,52 & 0,44 & 0,82 & 1,16 & 0,90 & 1,08 & 1,02 & 0,67 & 0,56 & 0,52 & 0,64 \\
\hline $\begin{array}{l}23.2 \text { Fabricação de produtos derivados do } \\
\text { petróleo }\end{array}$ & 5,45 & 4,48 & 5,60 & 9,20 & 13,27 & 11,93 & 12,16 & 14,32 & 13,50 & 15,57 & 15,76 & 14,51 \\
\hline 23.4 Produção de álcool & 1,53 & 1,36 & 0,81 & 0,64 & 0,77 & 0,60 & 0,49 & 0,80 & 0,55 & 0,7 & 0,82 & 0,76 \\
\hline 27.4 Metalurgia de metais não-ferrosos & 1,25 & 1,48 & 1,38 & 1,80 & 1,78 & 1,73 & 1,77 & 1,79 & 1,92 & 1,54 & 2,04 & 1,79 \\
\hline $\begin{array}{l}\text { Cimento e outros produtos minerais não } \\
\text { metálicos }\end{array}$ & 1,83 & 2,00 & 2,51 & 2,19 & 2,29 & 2,52 & 2,52 & 2,39 & 2,03 & 1,71 & 1,82 & 1,71 \\
\hline Intensiva em trabalho & 13,56 & 12,56 & 12,90 & 12,15 & 11,50 & 11,22 & 10,69 & 9,88 & 9,69 & 9,81 & 9,62 & 10,17 \\
\hline 17 Fabricação de produtos têxteis & 3,26 & 2,86 & 2,93 & 3,06 & 2,84 & 2,54 & 2,45 & 2,21 & 2,17 & 2,01 & 1,96 & 1,88 \\
\hline $\begin{array}{l}18 \text { Confecção de artigos do vestuário e } \\
\text { acessórios }\end{array}$ & 2,30 & 2,09 & 2,15 & 1,95 & 1,76 & 1,69 & 1,48 & 1,37 & 1,30 & 1,38 & 1,48 & 1,82 \\
\hline $\begin{array}{l}\text { 19.2 Fabricação de artigos para viagem e de } \\
\text { artefatos diversos de couro }\end{array}$ & 0,11 & 0,11 & 0,11 & 0,11 & 0,14 & 0,13 & 0,11 & 0,08 & 0,08 & 0,08 & 0,08 & 0,08 \\
\hline Calçados & 1,83 & 1,52 & 1,46 & 1,55 & 1,52 & 1,63 & 1,64 & 1,62 & 1,52 & 1,22 & 1,23 & 1,19 \\
\hline $\begin{array}{l}28 \text { Fabricação de produtos de metal - exceto } \\
\text { máquinas e equipamentos }\end{array}$ & 3,81 & 3,75 & 3,87 & 3,39 & 3,11 & 3,29 & 3,15 & 2,89 & 3,05 & 3,59 & 3,27 & 3,57 \\
\hline 36 Fabricação de móveis e indústrias diversas & 2,25 & 2,23 & 2,38 & 2,09 & 2,13 & 1,94 & 1,86 & 1,71 & 1,57 & 1,53 & 1,6 & 1,63 \\
\hline Intensiva em escala & 35,78 & 36,91 & 35,79 & 33,80 & 33,19 & 31,69 & 32,64 & 33,15 & 35,61 & 34,44 & 33,56 & 34,63 \\
\hline 26.4 Fabricação de produtos cerâmicos & 0,97 & 1,00 & 1,00 & 0,89 & 0,80 & 0,73 & 0,77 & 0,69 & 0,68 & 0,68 & 0,74 & 0,73 \\
\hline $\begin{array}{l}\text { Fabricação de produtos e artefatos de papel e } \\
\text { papelão }\end{array}$ & 3,07 & 2,90 & 3,07 & 3,20 & 3,13 & 2,95 & 3,43 & 3,31 & 3,18 & 2,78 & 2,96 & 2,8 \\
\hline $\begin{array}{l}22 \text { Edição, impressão e reprodução de } \\
\text { gravações }\end{array}$ & 4,92 & 5,25 & 5,25 & 4,18 & 4,08 & 3,69 & 3,22 & 2,92 & 2,92 & 2,93 & 2,87 & 2,78 \\
\hline Produtos químicos & 9,24 & 9,36 & 9,01 & 10,33 & 9,02 & 9,03 & 8,53 & 8,38 & 8,81 & 8,67 & 8,23 & 8,45 \\
\hline 25 Fabricação de artigos de borracha e plástico & 4,06 & 4,05 & 3,99 & 3,79 & 3,64 & 3,17 & 3,23 & 3,84 & 3,47 & 3,44 & 3,3 & 3,27 \\
\hline Vidro e produtos de vidro & 0,61 & 0,65 & 0,55 & 0,60 & 0,59 & 0,58 & 0,60 & 0,56 & 0,60 & 0,56 & 0,53 & 0,53 \\
\hline 27 Metalurgia básica & 4,15 & 4,34 & 4,21 & 4,21 & 4,58 & 4,44 & 5,22 & 5,34 & 7,40 & 6,55 & 5,75 & 6,11 \\
\hline $\begin{array}{l}34 \text { Fabricação e montagem de veículos } \\
\text { automotores, reboques e carrocerias }\end{array}$ & 8,12 & 8,65 & 8,00 & 6,01 & 6,83 & 6,49 & 6,97 & 7,37 & 7,69 & 7,87 & 7,98 & 8,6 \\
\hline $\begin{array}{l}\text { Equipamentos de transporte ferroviário, naval } \\
\text { e outros (exceto aeronáuticos) }\end{array}$ & 0,64 & 0,71 & 0,71 & 0,59 & 0,52 & 0,61 & 0,67 & 0,74 & 0,86 & 0,96 & 1,2 & 1,36 \\
\hline Diferenciada & 12,98 & 13,03 & 12,02 & 11,20 & 11,18 & 11,82 & 11,18 & 9,60 & 10,00 & 10,03 & 10,22 & 10,56 \\
\hline 29 Fabricação de máquinas e equipamentos & 6,81 & 6,94 & 6,40 & 5,75 & 5,28 & 5,92 & 6,07 & 5,71 & 5,82 & 5,22 & 5,41 & 5,84 \\
\hline $\begin{array}{l}31 \text { Fabricação de máquinas, aparelhos e } \\
\text { materiais elétricos }\end{array}$ & 2,12 & 2,19 & 2,30 & 2,06 & 2,03 & 2,17 & 1,92 & 1,69 & 1,65 & 2,37 & 2,24 & 2,44 \\
\hline $\begin{array}{l}32 \text { Fabricação de material eletrônico e de } \\
\text { aparelhos e equipamentos de comunicações }\end{array}$ & 3,55 & 3,39 & 2,78 & 2,88 & 3,36 & 3,28 & 2,73 & 1,75 & 2,12 & 1,99 & 2,12 & 1,83 \\
\hline $\begin{array}{l}\text { 33.1 Fabricação de aparelhos e instrumentos } \\
\text { para usos médicos-hospitalares, odontológicos } \\
\text { e de laboratórios e aparelhos ortopédicos }\end{array}$ & 0,29 & 0,29 & 0,31 & 0,30 & 0,30 & 0,25 & 0,29 & 0,28 & 0,27 & 0,32 & 0,31 & 0,3 \\
\hline Instrumentos ópticos, cronômetros e relógios & 0,21 & 0,22 & 0,23 & 0,21 & 0,21 & 0,20 & 0,17 & 0,17 & 0,14 & 0,13 & 0,14 & 0,15 \\
\hline Baseada em ciência & 4,96 & 5,33 & 5,89 & 6,02 & 5,75 & 6,06 & 5,40 & 4,82 & 4,54 & 4,78 & 4,65 & 4,59 \\
\hline Produtos farmacêuticos & 3,42 & 3,49 & 3,68 & 3,64 & 2,88 & 2,54 & 2,62 & 2,45 & 2,32 & 2,65 & 2,73 & 2,61 \\
\hline $\begin{array}{l}30 \text { Fabricação de máquinas para escritório e } \\
\text { equipamentos de informática }\end{array}$ & 0,49 & 0,54 & 0,56 & 0,76 & 1,11 & 1,34 & 0,72 & 0,60 & 0,47 & 0,55 & 0,57 & 0,63 \\
\hline $\begin{array}{l}\text { Equipamentos de distribuição de energia } \\
\text { elétrica }\end{array}$ & 0,51 & 0,63 & 0,85 & 0,41 & 0,39 & 0,42 & 0,35 & 0,54 & 0,40 & 0,58 & 0,38 & 0,34 \\
\hline $\begin{array}{l}\text { 33.2 Fabricação de aparelhos e instrumentos } \\
\text { de medida, teste e controle - exceto } \\
\text { equipamentos para controle de processos } \\
\text { industriais }\end{array}$ & 0,26 & 0,25 & 0,26 & 0,25 & 0,28 & 0,27 & 0,25 & 0,18 & 0,22 & 0,25 & 0,22 & 0,27 \\
\hline $\begin{array}{l}\text { 33.3 Fabricação de máquinas, aparelhos e } \\
\text { equipamentos de sistemas eletrônicos } \\
\text { dedicados à automação industrial e controle } \\
\text { do processo produtivo }\end{array}$ & 0,08 & 0,08 & 0,09 & 0,08 & 0,08 & 0,07 & 0,08 & 0,06 & 0,06 & 0,06 & 0,08 & 0,08 \\
\hline $\begin{array}{l}35.3 \text { Construção, montagem e reparação de } \\
\text { aeronaves }\end{array}$ & 0,20 & 0,34 & 0,45 & 0,88 & 1,01 & 1,42 & 1,38 & 0,99 & 1,07 & 0,69 & 0,67 & 0,66 \\
\hline
\end{tabular}

Fonte: Nassif (2008) de 1996 a 2004; PIA-IBGE de 2005 a 2007. 
A tabela 2 mostra a participação dos setores industriais nas exportações brasileiras, subdividida de acordo com seu fator de uso intensivo, como recursos naturais, trabalho, escala, ciência e indústria diferenciada, entre 2005 e 2010. De acordo com os dados apresentados na tabela 2, houve um aumento significativo da participação do setor industrial intensivo em recursos naturais, de 40,58\%, em 2005, para 48,63\%, em 2010, este impulsionado principalmente pelo aumento de exportação de petróleo, que cresceu neste período de $3,51 \%$ para $8,07 \%$. O setor intensivo em trabalho obteve queda de $2,84 \%$ para $1,44 \%$, o setor intensivo em escala caiu de $10,65 \%$ para $6,88 \%$, enquanto o diferenciado caiu de $2,72 \%$ para $1,74 \%$ e, por fim, o setor baseado em ciência também teve queda, de $6,38 \%$ para $4,26 \%$.

O aumento na participação do setor intensivo em recursos naturais e a pequena redução da participação dos demais setores, de acordo com os argumentos teóricos da doença holandesa, sinalizam que pode estar havendo um início de processo de doença holandesa no Brasil, porém se manifestando apenas como uma reprimarização da pauta de exportações e não como um processo de desindustrialização, como a tabela 1 já havia mostrado. Apenas com a manutenção deste cenário e com um impacto efetivo sobre a produção industrial seria possível afirmar que o país estivesse sofrendo da doença holandesa.

Ainda que os dados brasileiros apresentem tal desempenho, conforme Nassif (2008), isto pode ser fruto de uma alteração no padrão de especialização internacional, pois os dados de participação setorial no PIB total não apresentam tendência de aumento significativo da participação do setor intensivo em recursos naturais, acompanhado de uma redução da participação dos demais setores. No Brasil, portanto, há alguns sintomas da doença holandesa presentes, que estão contribuindo para a reprimarização da pauta de exportações. No entanto, não há sinais definitivos de sua presença no país, pois não houve redução significativa da participação industrial no PIB total, ou seja, não há ainda evidências robustas de um processo de desindustrialização. 
Tabela 2 - Participação setorial nas exportações brasileiras de 2005 a 2010

\begin{tabular}{|c|c|c|c|c|c|c|}
\hline SETC & 2005 & 2006 & 2007 & 2008 & 2009 & 2010 \\
\hline Intensiva em recursos naturais & $40,58 \%$ & $42,37 \%$ & $43,64 \%$ & $45,85 \%$ & $44,58 \%$ & $48,63 \%$ \\
\hline EXTRAÇÃO DE CARVÃO MINERAL & $0,00 \%$ & $0,00 \%$ & $0,00 \%$ & $0,00 \%$ & $0,00 \%$ & $0,00 \%$ \\
\hline EXTRAÇÃO DE PETRÓLEO E GÁS NATURAL & $3,51 \%$ & $5,00 \%$ & $5,54 \%$ & $6,91 \%$ & $6,11 \%$ & $8,07 \%$ \\
\hline EXTRAÇÃO DE MINERAIS METÁLICOS NÃO-FERROSOS & $0,60 \%$ & $0,59 \%$ & $0,90 \%$ & $1,10 \%$ & $0,79 \%$ & $0,95 \%$ \\
\hline EXTRAÇÃO DE OUTROS MINERAIS NÃO-METÁLICOS & $0,14 \%$ & $0,12 \%$ & $0,11 \%$ & $0,11 \%$ & $0,13 \%$ & $0,11 \%$ \\
\hline FABRICAÇÃO DE BEBIDAS & $0,08 \%$ & $0,18 \%$ & $0,08 \%$ & $0,06 \%$ & $0,06 \%$ & $0,05 \%$ \\
\hline $\begin{array}{l}\text { ABATE E PREPARAÇÃO DE PRODUTOS DE CARNE E DE } \\
\text { PESCADO }\end{array}$ & $7,27 \%$ & $6,57 \%$ & $7,26 \%$ & $7,55 \%$ & $7,87 \%$ & $6,89 \%$ \\
\hline FABRICAÇÃO DE OUTROS PRODUTOS ALIMENTÍCIOS & $0,83 \%$ & $0,72 \%$ & $0,73 \%$ & $0,74 \%$ & $0,79 \%$ & $0,70 \%$ \\
\hline FABRICAÇÃO DE PRODUTOS DO FUMO & $1,41 \%$ & $1,24 \%$ & $1,38 \%$ & $1,37 \%$ & $1,96 \%$ & $1,34 \%$ \\
\hline $\begin{array}{l}\text { PROCESSAMENTO, PRESERVAÇÃO E PRODUÇÃO DE } \\
\text { CONSERVAS DE FRUTAS, LEGUMES E OUTROS VEGETAIS }\end{array}$ & $1,32 \%$ & $1,41 \%$ & $1,78 \%$ & $1,33 \%$ & $1,45 \%$ & $1,19 \%$ \\
\hline CURTIMENTO E OUTRAS PREPARAÇÕES DE COURO & $1,18 \%$ & $1,36 \%$ & $1,36 \%$ & $0,95 \%$ & $0,76 \%$ & $0,86 \%$ \\
\hline EXTRAÇÃO DE MINÉRIO DE FERRO & $6,16 \%$ & $6,49 \%$ & $6,57 \%$ & $8,36 \%$ & $8,66 \%$ & $14,32 \%$ \\
\hline DESDOBRAMENTO DE MADEIRA & $1,19 \%$ & $1,13 \%$ & $1,05 \%$ & $0,70 \%$ & $0,58 \%$ & $0,51 \%$ \\
\hline PRODUÇÃO DE ÓLEOS E GORDURAS VEGETAIS E ANIMAIS & $3,59 \%$ & $2,71 \%$ & $2,97 \%$ & $3,64 \%$ & $3,89 \%$ & $3,07 \%$ \\
\hline $\begin{array}{l}\text { FABRICAÇÃO DE CELULOSE E OUTRAS PASTAS PARA A } \\
\text { FABRICAÇÃO DE PAPEL }\end{array}$ & $1,72 \%$ & $1,80 \%$ & $1,88 \%$ & $1,98 \%$ & $2,17 \%$ & $2,36 \%$ \\
\hline FABRICAÇÃO DE PRODUTOS DERIVADOS DO PETRÓLEO & $2,44 \%$ & $2,66 \%$ & $2,70 \%$ & $2,47 \%$ & $2,08 \%$ & $1,57 \%$ \\
\hline SIDERURGIA & $5,26 \%$ & $4,83 \%$ & $4,02 \%$ & $3,85 \%$ & $2,88 \%$ & $2,78 \%$ \\
\hline PRODUÇÃO DE ÁLCOOL & $0,63 \%$ & $1,04 \%$ & $0,90 \%$ & $1,20 \%$ & $0,87 \%$ & $0,50 \%$ \\
\hline METALURGIA DE METAIS NÃO-FERROSOS & $3,26 \%$ & $4,50 \%$ & $4,39 \%$ & $3,53 \%$ & $3,52 \%$ & $3,33 \%$ \\
\hline $\begin{array}{l}\text { FABRICAÇÃO DE ARTEFATOS DE CONCRETO, CIMENTO, } \\
\text { FIBROCIMENTO, GESSO E ESTUQUE }\end{array}$ & $0,01 \%$ & $0,02 \%$ & $0,01 \%$ & $0,01 \%$ & $0,03 \%$ & $0,02 \%$ \\
\hline Intensiva em trabalho & $2,84 \%$ & $2,37 \%$ & $2,17 \%$ & $1,85 \%$ & $1,73 \%$ & $1,44 \%$ \\
\hline FABRICAÇÃO DE ARTEFATOS TÊXTEIS, INCLUINDO TECELAGEM & $0,33 \%$ & $0,24 \%$ & $0,22 \%$ & $0,15 \%$ & $0,13 \%$ & $0,10 \%$ \\
\hline CONFECÇÃO DE ARTIGOS DO VESTUÁRIO & $0,28 \%$ & $0,20 \%$ & $0,16 \%$ & $0,11 \%$ & $0,10 \%$ & $0,08 \%$ \\
\hline $\begin{array}{l}\text { FABRICAÇÃO DE ARTIGOS PARA VIAGEM E DE ARTEFATOS } \\
\text { DIVERSOS DE COURO }\end{array}$ & 0,11 & $0,08 \%$ & $0,07 \%$ & $0,06 \%$ & $0,07 \%$ & $0,05 \%$ \\
\hline FABRICAÇÃO DE CALÇADOS & $1,67 \%$ & $1,43 \%$ & $1,27 \%$ & $1,02 \%$ & $0,97 \%$ & $0,82 \%$ \\
\hline FABRICAÇÃO DE PRODUTOS DIVERSOS DE METAL & $0,45 \%$ & $0,42 \%$ & $0,46 \%$ & $0,50 \%$ & $0,47 \%$ & $0,40 \%$ \\
\hline Intensiva em escala & $10,65 \%$ & $9,86 \%$ & $8,97 \%$ & $7,88 \%$ & $6,38 \%$ & $6,88 \%$ \\
\hline FABRICAÇÃO DE PRODUTOS CERÂMICOS & $0,49 \%$ & $0,46 \%$ & $0,38 \%$ & $0,28 \%$ & $0,26 \%$ & $0,21 \%$ \\
\hline $\begin{array}{l}\text { FABRICAÇÃO DE ARTEFATOS DIVERSOS DE PAPEL, PAPELÃO, } \\
\text { CARTOLINA E CARTÃO }\end{array}$ & $0,06 \%$ & $0,06 \%$ & $0,04 \%$ & $0,04 \%$ & $0,05 \%$ & $0,04 \%$ \\
\hline EDIÇÃO; EDIÇÃO E IMPRESSÃO & $0,08 \%$ & $0,10 \%$ & $0,07 \%$ & $0,05 \%$ & $0,04 \%$ & $0,03 \%$ \\
\hline $\begin{array}{l}\text { FABRICAÇÃO DE PRODUTOS E PREPARADOS QUÍMICOS } \\
\text { DIVERSOS }\end{array}$ & $0,80 \%$ & $0,71 \%$ & $0,70 \%$ & $0,69 \%$ & $0,69 \%$ & $0,65 \%$ \\
\hline FABRICAÇÃO DE PRODUTOS DE PLÁSTICO & $0,53 \%$ & $0,55 \%$ & $0,52 \%$ & $0,50 \%$ & $0,58 \%$ & $0,53 \%$ \\
\hline FABRICAÇÃO DE ARTIGOS DE BORRACHA & $0,92 \%$ & $0,95 \%$ & $1,08 \%$ & $0,95 \%$ & $0,93 \%$ & $0,87 \%$ \\
\hline FABRICAÇÃO DE VIDRO E DE PRODUTOS DO VIDRO & $0,25 \%$ & $0,23 \%$ & $0,24 \%$ & $0,18 \%$ & $0,17 \%$ & $0,16 \%$ \\
\hline $\begin{array}{l}\text { FORJARIA, ESTAMPARIA, METALURGIA DO PÓ E SERVIÇOS DE } \\
\text { TRATAMENTO DE METAIS }\end{array}$ & $0,04 \%$ & $0,04 \%$ & $0,03 \%$ & $0,03 \%$ & $0,02 \%$ & $0,02 \%$ \\
\hline FABRICAÇÃO DE CAMINHÕES E ÔNIBUS & $2,86 \%$ & $2,54 \%$ & $2,48 \%$ & $2,23 \%$ & $1,21 \%$ & $1,56 \%$ \\
\hline $\begin{array}{l}\text { FABRICAÇÃO DE AUTOMÓVEIS, CAMINHONETAS E } \\
\text { UTILITÁRIOS }\end{array}$ & $4,65 \%$ & $4,28 \%$ & $3,48 \%$ & $3,00 \%$ & $2,48 \%$ & $2,68 \%$ \\
\hline $\begin{array}{l}\text { CONSTRUÇÃO, MONTAGEM E REPARAÇÃO DE VEÍCULOS } \\
\text { FERROVIARIOS }\end{array}$ & $0,23 \%$ & $0,18 \%$ & $0,19 \%$ & $0,11 \%$ & $0,12 \%$ & $0,28 \%$ \\
\hline Diferenciada & $2,72 \%$ & $2,54 \%$ & $2,53 \%$ & $2,41 \%$ & $1,72 \%$ & $1,74 \%$ \\
\hline FABRICAÇÃO DE MÁQUINAS E EQUIPAMENTOS DE USO GERAL & $0,60 \%$ & $0,51 \%$ & $0,52 \%$ & $0,51 \%$ & $0,51 \%$ & $0,36 \%$ \\
\hline $\begin{array}{l}\text { FABRICAÇÃO DE MÁQUINAS E EQUIPAMENTOS DE USO NA } \\
\text { EXTRAÇÃO MINERAL E CONSTRUÇÃO }\end{array}$ & $1,78 \%$ & $1,68 \%$ & $1,67 \%$ & $1,63 \%$ & $0,89 \%$ & $1,11 \%$ \\
\hline $\begin{array}{l}\text { FABRICAÇÃO DE OUTROS EQUIPAMENTOS E APARELHOS } \\
\text { ELÉTRICOS }\end{array}$ & $0,08 \%$ & $0,08 \%$ & $0,07 \%$ & $0,04 \%$ & $0,04 \%$ & $0,03 \%$ \\
\hline $\begin{array}{l}\text { FABRICAÇÃO DE APARELHOS E INSTRUMENTOS PARA USOS } \\
\text { MÉDICOS-HOSPITALARES, ODONTOLÓGICOS E DE } \\
\text { LABORATÓRIOS E APARELHOS ORTOPÉDICOS }\end{array}$ & $0,22 \%$ & $0,23 \%$ & $0,24 \%$ & $0,20 \%$ & $0,25 \%$ & $0,21 \%$ \\
\hline $\begin{array}{l}\text { FABRICAÇÃO DE APARELHOS, INSTRUMENTOS E MATERIAIS } \\
\text { ÓPTICOS, FOTOGRÁFICOS E CINEMATOGRÁFICOS }\end{array}$ & $0,04 \%$ & $0,04 \%$ & $0,03 \%$ & $0,03 \%$ & $0,03 \%$ & $0,02 \%$ \\
\hline FABRICAÇÃO DE CRONÔMETROS E RELÓGIOS & $0,00 \%$ & $0,00 \%$ & $0,00 \%$ & $0,00 \%$ & $0,00 \%$ & $0,00 \%$ \\
\hline Baseada em ciência & $6,38 \%$ & $5,95 \%$ & $5,57 \%$ & $5,30 \%$ & $6,06 \%$ & $4,26 \%$ \\
\hline FABRICAÇÃO DE PRODUTOS FARMACÊUTICOS & $0,60 \%$ & $0,65 \%$ & $0,65 \%$ & $0,65 \%$ & $0,94 \%$ & $0,80 \%$ \\
\hline FABRICAÇÃO DE MÁQUINAS PARA ESCRITÓRIO & $0,09 \%$ & $0,11 \%$ & $0,06 \%$ & $0,04 \%$ & $0,03 \%$ & $0,04 \%$ \\
\hline $\begin{array}{l}\text { PRODUÇÃO E DISTRIBUIÇÃO DE ENERGIA ELÉTRICA } \\
\text { FABRICAÇÃO DE APARELHOS E EQUIPAMENTOS DE TEL }\end{array}$ & $0,00 \%$ & $0,00 \%$ & $0,00 \%$ & $0,02 \%$ & $0,72 \%$ & $0,17 \%$ \\
\hline $\begin{array}{l}\text { E RADIOTELEFONIA E DE TRANSMISSORES DE TELEVISÃO E } \\
\text { RÁDIO }\end{array}$ & $2,33 \%$ & $2,21 \%$ & $1,36 \%$ & $1,27 \%$ & $1,15 \%$ & $0,69 \%$ \\
\hline FABRICAÇÃO DE MÁQUINAS, APARELHOS E EQUIPAMENTO & & & & & & \\
\hline $\begin{array}{l}\text { DE SISTEMAS ELETRÔNICOS DEDICADOS À AUTOMAÇÃO } \\
\text { INDUSTRIAL E CONTROLE DO PROCESSO PRODUTIVO }\end{array}$ & $0,08 \%$ & $0,09 \%$ & $0,08 \%$ & $0,07 \%$ & $0,08 \%$ & $0,07 \%$ \\
\hline CONSTRUÇÃO, MONTAGEM E REPARAÇÃO DE AERONAVES & $3,12 \%$ & $2,72 \%$ & $3,24 \%$ & $3,06 \%$ & $2,97 \%$ & $2,32 \%$ \\
\hline
\end{tabular}

Fonte: PIA-IBGE. 


\section{CONCLUSÃO}

Após apresentar os conceitos da doença holandesa e identificar os fatores causadores da mesma, pôde-se compreender o que é o fenômeno e sua dimensão na economia de um país. Além de prejudicar o desenvolvimento econômico dos países afetados, a doença é de difícil identificação e neutralização, pois por mais que os seus principais sintomas, tais como commoditização da pauta de exportações, valorização cambial e redução da participação da indústria no PIB e no emprego, detalhados neste trabalho sejam claros, as experiências históricas indicam que outros fatores macroeconômicos envolvidos dificultam muito o discernimento entre a ocorrência da doença e outros fenômenos macroeconômicos conhecidos.

No caso brasileiro, os autores consultados apresentaram diferentes visões e argumentos quanto à hipótese de ocorrência da doença holandesa no país, alguns defendendo a sua ocorrência e outros a refutando. Os autores que defendem o argumento afirmam que houve o aumento da participação das commodities na pauta de exportação, apreciação cambial e redução da participação da indústria no PIB e no emprego, porém não se baseiam em estudos empíricos. Por sua vez, os autores que refutam a hipótese da doença utilizam dados analíticos, que apontam um leve crescimento dos setores intensivos em tecnologia e baseados em ciência, juntamente com o setor primário, e isto, segundo eles, seria efeito das oportunidades de expansão econômica mundial, resultado de uma mudança no padrão de especialização internacional.

Com base na análise de Nassif (2008), foi feita uma atualização dos dados utilizados pelo autor para que fosse possível verificar a presença da doença no país no período mais recente, entre 2005 e 2010 . Foi possível observar que a participação setorial no PIB, quanto aos recursos utilizados intensivamente, não demonstra ocorrência de doença holandesa, porém a participação destes setores na exportação aponta para uma reprimarização da pauta de exportações do país que, eventualmente, poderá levar à doença. É necessário cautela no diagnóstico, pois o cenário deverá se manter desta maneira, com o aumento da participação das commodities na pauta de exportações em detrimento dos outros setores, afetando negativamente também a produção industrial para que se possa afirmar que o Brasil esteja sofrendo da doença holandesa. 


\section{REFERÊNCIAS BIBLIOGRÁFICAS}

BRESSER-PEREIRA, L. C. ; MARCONI, Nelson . Existe doença holandesa no Brasil? In: Luiz Carlos Bresser Pereira. (Org.). Doença holandesa e indústria. Rio de Janeiro: Editora FGV, 2010, p. 207-230.

BRESSER PEREIRA, Luiz C. The Dutch Disease and its neutralization: a Ricardian approach. Revista de Economia Política, São Paulo, v. 28, p. 48-71, Jan/Mar, 2008.

CORDEN, Max W.; NEARY, Peter J. Booming Sector and De-Industrialization in a Small Open Economy. The Economic Journal, v. 92, p. 825-848, 1982.

GALA, Paulo Sérgio O. Política Cambial e Macroeconomia do Desenvolvimento. 2006. 167f. Tese (Doutorado) Programa de Pós-Graduação da USP, São Paulo, São Paulo.

GOMES BATISTA, Biano G. O Boom do Minério de Ferro na Economia Brasileira: Houve Dutch Disease? 2009. 111f. Tese (Mestrado), Programa de Pós-Graduação da Universidade Federal de Ouro Preto, Minas Gerais.

LACERDA, Antônio C.; NOGUEIRA, Rodrigo H. Novas Evidências Sobre os Impactos da Valorização Cambial na Estrutura Produtiva Brasileira. Seminário PUC-SP, São Paulo, 2008.

NAKAHOTO, Sydnei N.; JANK, Marcos S. A Falácia da Doença Holandesa no Brasil. Documento de Pesquisa, Instituto do Comércio e Negociações Internacionais, São Paulo, 2006.

NASSIF, André. Há evidências de desindustrialização no Brasil? Revista de Economia Política, São Paulo, v.28, p.72-96, 2008.

ONYEUKWU, Agwara J. Resource Curse in Nigeria: Perception and Challenges. International Policy Fellowship Program, Open Society Institute, 2007.

OOMES, Nienke; KALCHEVA, Katerina. Diagnosing Dutch Disease: Does Russia Have the Symptoms? IMF Working Papers 07/102, International Monetary Fund, 2007.

PAVITT, Keith. Sectorial Patterns of Technical Change: Towards a Taxonomy and a Theory. Research Policy, v.13, p. 343-373,1984.

PENN WORLD TABLE - Pennsylvania World Table (Online). Disponível em: http://pwt.econ.upenn.edu/php site/pwt index.php. Acesso em 11 fevereiro de 2011.

PIA-IBGE - Pesquisa Industrial Anual (Online). Disponível em: http://www.ibge.gov.br/home/estatistica/economia/industria/pia/default.shtm. Acesso em 10 junho de 2011. 
ROCHA, Marcos; MARCONI, Nelson. A tendência à Apreciação da Taxa de Câmbio e Dutch Disease: Uma Primeira Aproximação. III Encontro da Associação Keynesiana Brasileira, São Paulo, 2010.

RUEHLE, Alex A.; KULKARNI, Kishore G. Dutch Disease and the Chilean Copper Boom. Denver, University of Denver, 2008, 31 p.

RYBCZYNSKI, Tadeusz N. Factor endowments and relative commodity prices. Economica, Londres, v. 22, p. 336-341, 1955.

SOUZA, Cristiano R. O Brasil Pegou a Doença Holandesa? 2009. 151f. Tese (Doutorado), Faculdade de Economia, Administração e Contabilidade da Universidade de São Paulo, São Paulo.

SQUEFF, Gabriel C. Desindustrialização: luzes e sombras no debate brasileiro. Texto para Discussão nº 1747, Brasília, DF: IPEA, 2012.

THE ECONOMIST, 8 de março 1997. Boom and gloom. Disponível em http://www.economist.com/node/8819945, acessado em 14 de outubro de 2010.

WORLD BANK DATA - The World Bank (Online). Disponível em: <http://data.worldbank.org/>. Acesso em 11 de fevereiro de 2011. 